\title{
The Best of Europe: Abstracts from the 2nd EASAPS Meeting, Cardiff, Wales, 2009
}

\author{
Cristino Suárez López de Vergara
}

Published online: 17 September 2010

(c) Springer Science+Business Media, LLC and International Society of Aesthetic Plastic Surgery 2010

The idea behind the creation of a European Association of Societies of Aesthetic Plastic Surgery (EASAPS) was initiated in the city of Valladolid, Spain in the year 2001 during the celebration of the second congress of the Spanish Association of Aesthetic Plastic Surgery (AECEP). The principal inspirations behind this idea were Drs. Ulrich Hinderer, Jose Manuel Perez Macias, and Yann Levet.

The project was initiated during the celebration of a congress between the French and Spanish Societies, similar to the celebration of the Spanish-French congress in the city of Barcelona, Spain in 2004. The plan reached the highest point during the initial development with the creation of EASAPS in the city of Burdeos, France in 2007. During this period, the European Association paved the way with the introduction of three members: France, Spain, and England.

Three European congresses were convened. The first was held in the city of Madrid, Spain under the presidency of Dr. Antonio de la Fuente. The second was celebrated in the Welsh city of Cardiff in 2009 under the presidency of Dr. Nigel Mercer. The third and last congress was celebrated in 2010 in the German city of Aachen under the presidency of Dr. Norbert Pallua.

Future congresses will be planned in countries that are members of the European congress during a 1-year period under the umbrella of the national society that organizes each congress. The next congress will be located in Milan in 2011 under the presidency of Dr. Andrea Grisotti, and the following congress will be held in Switzerland to coincide with the ISAPS congress organized by Dr. Jan Poell.

One objective of the European Association is to promote, disseminate, and defend the field of aesthetic plastic surgery in all the countries that are members of the European Association. Part of this objective will be the creation of The Best of Europe presentation held every year to acknowledge the contribution of members from every country for their work in the National Society. This communication is presented at each European congress in the special section dedicated to The Best of Europe for that year. The abstracts of The Best of Europe are published in Aesthetic Plastic Surgery after the celebration of each congress of the European Association.

In conclusion, EASAPS is an Association of Societies of Aesthetic Plastic Surgery that 3 years after its founding has 17 European countries as members and represents 3,000 European plastic surgeons. We have a good idea of the society's potential. In the near future, we hope that all European countries will be represented in this association.

The completed work to date has been difficult, and it would be impossible to name all the participants in the project, but our heartfelt thanks go out to all for their efforts.

C. S. López de Vergara ( $₫)$

Cirugía Plástica y Estética, Av. La Asunción, 30-2 izq.,

Santa Cruz, Tenerife, Spain

e-mail: cristinosuarez@gmail.com 